\title{
Comparative effect of Piper betle, Chlorella vulgaris and tocotrienol-rich fraction on antioxidant enzymes activity in cellular ageing of human diploid fibroblasts
}

\author{
Suzana Makpol', Thong Wei Yeoh, Farah Adilah Che Ruslam, Khaizurin Tajul Arifin and Yasmin Anum Mohd Yusof
}

\begin{abstract}
Background: Human diploid fibroblasts (HDFs) undergo a limited number of cellular divisions in culture and progressively reach a state of irreversible growth arrest, a process termed cellular ageing. Even though beneficial effects of Piper betle, Chlorella vulgaris and tocotrienol-rich fraction (TRF) have been reported, ongoing studies in relation to ageing is of interest to determine possible protective effects that may reverse the effect of ageing. The aim of this study was to evaluate the effect of $P$. betle, $C$. vulgaris and TRF in preventing cellular ageing of HDFs by determining the activity of antioxidant enzymes viz; catalase, superoxide dismutase (SOD) and glutathione peroxidase.
\end{abstract}

Methods: Different passages of HDFs were treated with P. betle, C. vulgaris and TRF for $24 \mathrm{~h}$ prior to enzymes activity determination. Senescence-associated beta-galactosidase (SA $\beta$-gal) expression was assayed to validate cellular ageing.

Results: In cellular ageing of HDFs, catalase and glutathione peroxidase activities were reduced, but SOD activity was heightened during pre-senescence. P. betle exhibited the strongest antioxidant activity by reducing SA $\beta$-gal expression, catalase activities in all age groups, and SOD activity. TRF exhibited a strong antioxidant activity by reducing SA $\beta$-gal expression, and SOD activity in senescent HDFs. C. vulgaris extract managed to reduce SOD activity in senescent HDFs.

Conclusion: P. betle, C. vulgaris, and TRF have the potential as anti-ageing entities which compensated the role of antioxidant enzymes in cellular ageing of HDFs.

Keywords: Antioxidant, Piper betle, Chlorella vulgaris, Tocotrienol-rich fraction (TRF), Cellular ageing, Fibroblasts

\section{Background}

Ageing is a multi factorial process which involves progressive decline in body function and finally leads to death [1]. Cellular ageing or replicative senescence is a condition where the cell cycle arrest occurs permanently [2], when the cell fails to initiate DNA synthesis and transition from G1 to S phase of the cell cycle [3]. Studies on cellular senescence normally use fibroblast cell culture system which has a limited replicative ability. Senescent cells exhibit morphological changes such as cellular enlargement,

\footnotetext{
* Correspondence: suzanamakpol@yahoo.com

Department of Biochemistry, Faculty of Medicine, Universiti Kebangsaan

Malaysia, Jalan Raja Muda Abdul Aziz, Kuala Lumpur 50300, Malaysia
}

loss of contact inhibition and become less polar [4]. Senescence-associated $\beta$-galactosidase is one of the markers widely used to indicate replicative senescence since its activity increases with passage of time [5].

According to Harman's hypothesis (1956), cells undergo ageing due to oxidative stress, which is caused by the presence of free radicals [6]. Utilization of oxygen molecule during normal metabolism within the cell is the main source of free radicals [7]. When an overproduction of free radicals and reactive oxygen species exceeds the capacity of antioxidant mechanism of the cells, the cells will experience oxidative stress [8]. 
Oxidative stress in tissues has been linked to ageing and degenerative diseases [9].

Many biological functions decline in ageing due to excessive production of reactive oxygen species over the antioxidant protective mechanism [10]. Previous study reported that the half life of an organism depends on the effectiveness to overcome the oxidative environment [11].

Aerobic organisms have their antioxidant defence mechanism which protects against oxidative stress such as the presence of antioxidant enzymes; superoxide dismutase, catalase and glutathione peroxidase. Superoxide dismutase catalyzes the conversion of superoxide anion to oxygen and hydrogen peroxide [12]. Catalase converts hydrogen peroxide to water and oxygen $[8,13]$ while glutathione peroxidase reduces hydrogen peroxide by oxidizing GSH (reduced glutathione) [8].

Piper betle (also identified as betel) Linn., locally known as sirih is a semi woody plant under family Piperaceae [14]. In many Asian countries, the leaves of the P. betle are used in masticatory for recreational and medicinal purposes [15]. The leaves of $P$. betle act as a potential source of natural antioxidants [9]. The antioxidant activity can be attributed to the phenolic compounds namely allylpyrocatechol and chavibetol, the main chemical compounds within the ethanolic extract of $P$. betle $[16,17]$. Three varieties of $P$. betle which are Kauri, Ghanagate and Bagerhati, are found to have higher potential than tea in preventing lipid peroxidation, and have the same antioxidant capacity as gallic acid [18]. Besides, essential oil of $P$. betle has a strong free radical scavenging activity and its activity is almost the same as ascorbic acid [19]. The compound allylpyrocatechol which is also found in the leaves has anti-inflammatory properties [20].

Chlorella vulgaris is a unicellular green alga [21] which can be found growing in fresh water [22]. Nutritional studies of Chlorella have revealed that this alga contains many intracellular phytochemicals namely carotenoids, chlorophyll, tocopherols, and ubiquinone; protein and others typical of green plants [23] besides flavonoid and polyphenol [24] which attributed to its antioxidant properties.

In Malaysia, palm oil is used as cooking oil. Tocotrienol-rich fraction (TRF) derived from palm oil consists of $\alpha$-tocopherol and $\alpha-, \beta-, \quad \gamma^{-}$, and $\delta$ tocotrienol; all of which are isomers of vitamin $E$, and potent membrane-soluble antioxidants [25].

$\alpha$-Tocopherol is an intracellular antioxidant which inhibits lipid peroxidation of polyunsaturated fatty acid located in lipid membrane [26]. Tocotrienol has been reported to have antioxidant property and suppressed reactive oxygen species production more efficiently than tocopherol [27], and showed promising non antioxidant activities in various in vitro and in vivo models [28].
In the present study, normal HDFs cells were used as our ageing model. Human diploid fibroblast (HDF) cells were sub cultured until passage 4, 15 and 30 which represent young, pre-senescent and senescent cells. The three age groups were treated with $P$. betle, C. vulgaris and TRF for 24 hours to evaluate the protective effect of these substances against cellular ageing, by measuring the activity of antioxidant enzymes.

\section{Methods}

\section{P. betle and C. vulgaris extracts, and TRF}

$P$. betle leaves were purchased from Ethnoresources Sdn. Bhd. (Sungai Buloh, Malaysia). The identification and voucher number (UKMB 29768) of the plant was obtained from Herbarium, Universiti Kebangsaan Malaysia, Bangi, Selangor, Malaysia. The extraction of $P$. betle was carried out as described by $\mathrm{SO}$ et al. [29]. Stock of C. vulgaris Beijerinck (strain 072) was obtained from University of Malaya Algae Culture Collection (UMACC, Kuala Lumpur, Malaysia). C. vulgaris was cultivated in the lab, and the hot water extraction of C. vulgaris was carried out as described by Saad et al. [30]. TRF Gold Tri E 50 which consists of $21.2 \% \alpha$-tocopherol and $78.9 \%$ tocotrienols was purchased from Sime Darby Bhd., Malaysia.

\section{Cell culture and the induction of senescence}

This research has been approved by the Universiti Kebangsaan Malaysia Ethical Committee (Approval Project Code: FF-104-2007). The primary HDF was derived and maintained as described by Makpol et al. (2011) [31]. Primary HDFs were derived from the foreskins of three 9 to 12 year-old boys after circumcision. Written informed consents were obtained from parents of all subjects. The samples were aseptically collected and washed several times with $75 \%$ alcohol and phosphate buffered saline (PBS) containing 1\% antibioticantimycotic solution (PAA, Austria). After removing the epidermis, the pure dermis was cut into small pieces and transferred into a falcon tube containing $0.03 \%$ collagenase type I solution (Worthington Biochemical Corporation, USA). Pure dermis was digested in the incubator shaker at $37^{\circ} \mathrm{C}$ for $6-12 \mathrm{~h}$. Then, cells were rinsed with PBS before being cultured in Dulbecco Modified Eagle Medium (DMEM) containing 10\% fetal bovine serum (FBS) (PAA, Austria) and $1 \%$ antibioticantimycotic solution at $37^{\circ} \mathrm{C}$ in $5 \% \mathrm{CO}_{2}$ humidified incubator. After 5-6 days, the cultured HDFs were harvested by trypsinization and culture expand into new T25 culture flasks (Nunc, Denmark) with expansion degree of $1: 4$. When the subcultures reached $80-90 \%$ confluence, serial passaging was done by trypsinization and the number of population doublings (PDs) was monitored until HDFs reached senescence. The cells were used at passage 4 (young cells, population 
doubling; $\mathrm{PD}<12$ ), passage 15 (pre-senescent cells, $30<$ $\mathrm{PD}<40$ ), and passage 30 (Senescent cells, PD>55) in subsequent experiments. Young HDFs were incubated with $0.5,0.4$ and $0.3 \mathrm{mg} / \mathrm{mL}$ of TRF, hot water extract of $C$. vulgaris or aqueous extract of $P$. betle respectively, pre-senescent HDFs were incubated with 0.5, 0.2 or $0.3 \mathrm{mg} / \mathrm{mL}$ of TRF, hot water extract of C. vulgaris or aqueous extract of $P$. betle respectively while senescent HDFs were incubated with $0.5,0.1$ or $0.2 \mathrm{mg} / \mathrm{mL}$ of TRF, hot water extract of $C$. vulgaris or aqueous extract of $P$. betle respectively for $24 \mathrm{~h}$. Untreated cells were cultured in DMEM containing 10\% FBS (PAA, Austria). The media for the untreated cells were changed in parallel to the treated cells. The untreated and treated cells were harvested on the same day.

\section{Morphology analysis and senescence-associated $\beta$-galactosidase (SA $\beta$-gal) staining}

The cells were divided into three experimental groups, based on their age: young, pre-senescent and senescent. Each group was treated with $P$. betle and $C$. vulgaris extracts, and TRF. SA $\beta$-gal activity, the molecular marker of HDF cellular ageing in vitro, was determined using a senescent cell staining kit (Sigma, USA) according to the manufacturer's instructions. Cells $\left(2 \times 10^{4}\right)$ cultured in a 6-well plate were washed twice with $1 \times$ PBS. Cells were then fixed with $1.5 \mathrm{~mL}$ of $1 \times$ fixation buffer and incubated at room temperature for 7 minutes. While waiting for incubation, staining mixture was prepared by mixing $1 \mathrm{~mL}$ of staining solution $10 \times, 125 \mu \mathrm{L}$ of reagent $\mathrm{B}, 125$ $\mu \mathrm{L}$ of reagent $\mathrm{C}, 250 \mu \mathrm{L}$ of $\mathrm{X}$-gal solution (pre-warmed for $1 \mathrm{~h}$ at $37^{\circ} \mathrm{C}$ ) and $8.5 \mathrm{~mL}$ of miliQ water. After 7 minutes, cells were washed for three times with $1 \times$ PBS, followed by the addition of $1 \mathrm{~mL}$ of the staining mixture. Cells were incubated in a humidified incubator at $37^{\circ} \mathrm{C}$ for $4 \mathrm{~h}$ without $\mathrm{CO}_{2}$ supply. Blue stain was visible after 4 $\mathrm{h}$ of incubation. Cells were viewed with an inverted light microscope using 100x magnification. A total of 100 cells were observed in eight random fields, and the number of blue cells was counted. The percentage of bluestained cells was calculated as the number of blue cells divided by the total of counted cells.

\section{Protein extraction}

Following the 24-h treatments, HDFs $\left(1 \times 10^{6}\right.$ cells $)$ were trypsinised ( $0.25 \%$ trypsin, Hyclone, Australia) and harvested by centrifugation. The cell pellets were washed with $600 \mu \mathrm{L}$ of cold PBS and incubated for 10 minutes in ice. The cell suspension was centrifuged at the maximum speed for 10 seconds at room temperature. The supernatant was discarded, while the pellets were stored at $4{ }^{\circ} \mathrm{C}$. A total of $200 \mu \mathrm{L}$ of lysis buffer were mixed with the pellets and incubated on ice for 30 minutes. The suspension was centrifuged at the maximum speed $\left(4^{\circ} \mathrm{C}\right.$ for
30 minutes), where the supernatant was collected and stored at $-80^{\circ} \mathrm{C}$.

\section{Determination of total protein concentration}

Total protein concentration was determined by using Bradford assay [32]. Briefly, $10 \mathrm{mg} / \mathrm{mL}$ of bovine serum albumin (Sigma, US) was prepared as standard protein solutions: $5,10,15,20,25,30$, and $35 \mu \mathrm{g} / \mathrm{mL}$ respectively. Then, $200 \mu \mathrm{L}$ of Bradford reagent (Bio-Rad) was added to the standard, totalling to $800 \mu \mathrm{L}$ as the final volume. Standards were prepared in duplicates, and the absorbance was measured at $595 \mathrm{~nm}$ using VersaMax tunable microplate reader (Molecular Devices, USA). Standard curve was plotted using the average of the duplicate. Concentrations of the samples were interpolated from the standard curve.

\section{Enzyme extraction}

Following the $24-\mathrm{h}$ treatments, HDFs $\left(1 \times 10^{6}\right.$ cells $)$ were trypsinised ( $0.25 \%$ trypsin, Hyclone, Australia) and harvested by centrifugation. One $\mathrm{mL}$ of PBS was used to wash the cells, followed by centrifugation at $600 \mathrm{rpm}$ for 10 minutes, at $4^{\circ} \mathrm{C}$. Then supernatant was discarded and the pellets were resuspended in $2 \mathrm{~mL}$ of $50 \mathrm{mM}$ PBS. The cells were sonicated for 2 minutes at $4^{\circ} \mathrm{C}$, followed by centrifugation at the maximum speed at $4^{\circ} \mathrm{C}$. The supernatant was collected and stored at $-80^{\circ} \mathrm{C}$.

\section{Catalase activity assay}

The activity of catalase was determined according to Aebi et al. (1984) [33]. A total of $700 \mu \mathrm{L}$ of enzyme extract and $350 \mu \mathrm{L}$ of $30 \mathrm{mM}$ hydrogen peroxide (Sigma, US) were mixed. The absorbance of the mixture was determined at $240 \mathrm{~nm} 30$ seconds later. Catalase activity was calculated by using the formula below:

Catalase Activity $(\mathrm{mU} / \mathrm{mg}$ protein $)=(2.3) \mathrm{x}-\log$ (OD) $/ \Delta \mathrm{t} \times$ d.f $\times 1 /[$ protein]

Remarks:

$\Delta \mathrm{t}=$ time (seconds)

d.f $=$ dilution factor $(3 \times)$

[protein $]=$ protein concentration $(\mathrm{mg} / \mathrm{ml})$

\section{Superoxide dismutase activity assay}

Superoxide dismutase (SOD) activity was determined according to Beyer and Fridovich (1987) [34]. Substrate of SOD (NBT) was freshly prepared for every assay, by adding $1.5 \mathrm{~mL}$ of $30 \mathrm{mg} / \mathrm{mL}$ L-methionine (Sigma, USA), $1 \mathrm{~mL}$ of $14.1 \mathrm{mg} / \mathrm{mL}$ nitroblue tetrazolium (Sigma, USA), and $1 \mathrm{~mL}$ of $1 \%$ Triton X (Sigma, USA) to $27 \mathrm{~mL}$ of 50 mM PBS pH 7.8 with EDTA. One mL of SOD substrate was mixed with $20 \mu \mathrm{L}$ of enzyme extract, followed by 10 $\mu \mathrm{L}$ of riboflavin (Sigma, USA). PBS was used as the negative control. Samples were incubated under $20 \mathrm{~W}$ light for 7 minutes, and the absorbance was measured at $560 \mathrm{~nm}$. 
The specific activity of SOD was calculated by the formula below:

Percentage of inhibition $=$ Absorbance $($ controlsample)/ Absorbance control $\times 100 \times$ d.f

Unit enzyme $=1$ unit inhibit $50 \%$ reduction rate of NBT

SOD specific activity $(\mathrm{mU} / \mathrm{mg}$ protein $)=$ Inhibition percentage $(\%) / \mathrm{V} \times$ [protein] $\times \mathrm{t}$

Remarks:

d.f = dilution factor

$\mathrm{V}=$ enzyme volume $(\mathrm{mL})$

[protein] $=$ protein concentration $(\mathrm{mg} / \mathrm{mL})$

$\mathrm{t}=$ time (minutes)

\section{Glutathione peroxidase activity assay}

Glutathione peroxidase (GPx) activity was determined according to the method by Paglia and Valentine (1967) [35]. GPx substrate was freshly prepared by adding 20 $\mu \mathrm{L}$ of glutathione reductase (Sigma, USA), $5 \mathrm{mg}$ reduced formed of glutathione (GSH) (Sigma, USA), $24 \mathrm{mg}$ of reduced formed of nicotinamide adenine dinucleotide phosphate (NADPH) (Sigma, USA), and $25 \mathrm{mg}$ of sodium azide (Hopkin \& William, England) into $100 \mathrm{~mL}$ of $50 \mathrm{mM}$ PBS pH 7.0 with EDTA.

$2.88 \mathrm{~mL}$ of substrate was added with $20 \mu \mathrm{L}$ enzyme extract in a cuvette. Then $100 \mu \mathrm{L}$ of $2.2 \mathrm{mM}$ of hydrogen peroxide (Sigma, US) was added. After 5 minutes, absorbance was measured at $340 \mathrm{~nm}$. PBS was used as the negative control. GPx specific activity was calculated by using the formula below:

$\mathrm{GP} \times$ specific activity $(\mathrm{mU} / \mathrm{mg}$ protein $)=(\Delta \mathrm{OD} /$ $\left.\min \times \mathrm{V}_{\mathrm{k}}\right) /\left(6.22 \mathrm{mM}^{-1} \times 1 \mathrm{~cm} \mathrm{x} \mathrm{V}_{\mathrm{s}} \times\right.$ [protein] $)$

Remarks:
$\Delta \mathrm{OD}=$ absorbance of sample - absorbance of control $6.22 \mathrm{mM}^{-1} \times 1 \mathrm{~cm}=$ molar extinction coefficient of $\mathrm{NADPH}$ at $340 \mathrm{~nm}$ with cuvette thickness $1 \mathrm{~cm}$.

$\mathrm{V}_{\mathrm{k}}=$ cuvette volume $(\mathrm{ml})$

$\mathrm{V}_{\mathrm{s}}=$ enzyme volume $(\mathrm{mL})$

[protein] $=$ protein concentration $(\mathrm{mg} / \mathrm{mL})$

\section{Statistical analysis}

The data were statistically analysed by one-way ANOVA. $\mathrm{P}<0.05$ was considered significant.

\section{Results}

\section{Cell morphology}

Morphological changes were observed with ageing of HDFs. Young HDFs displayed the normal spindle shape, common for fibroblasts (Figure 1a). With senescence, the cell volume and nucleus size of HDFs increased, and the cells became larger and flattened, while displaying increasing accumulation of vacuoles (Figure 1b-c). Morphologies of the senescent HDFs treated with the extracts and TRF were not affected (Figure 1d-f).

\section{SA $\beta$-gal expression}

Among the three age groups of HDFs, the senescent cells displayed the highest percentage $(70 \%)$ of blue-stained cells, while no blue-stained cells were observed in the other two groups (Figure 2). When the three groups were subjected to treatment with $P$. betle and $C$. vulgaris extracts and TRF, the treatments did not affect the young and pre-senescent HDFs, but the P. betle extract and TRF significantly reduced the number of blue-stained cells ( $45 \%$ and $40 \%$, respectively). However, treatment with C. vulgaris extract produced no significant difference.
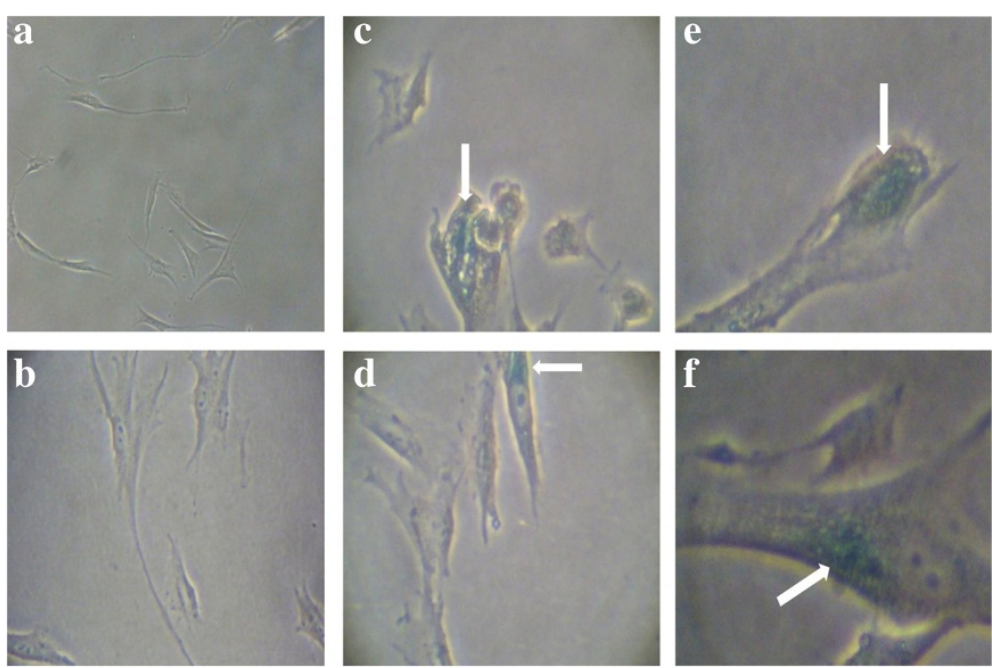

Figure 1 Morphological changes of HDFs in culture. Young (a), pre-senescent (b) senescent HDFs (c), senescent HDFs treated for $24 \mathrm{~h}$ with $0.2 \mathrm{mg} / \mathrm{ml}$ aqueous extract of $P$. betle (d), $0.1 \mathrm{mg} / \mathrm{ml}$ hot water extract of $C$. vulgaris (e), and $0.5 \mathrm{mg} / \mathrm{ml}$ TRF (f). Cells expressing SA $\beta$-gal were stained blue (white arrows). Micrographs are shown at 100x magnification. 


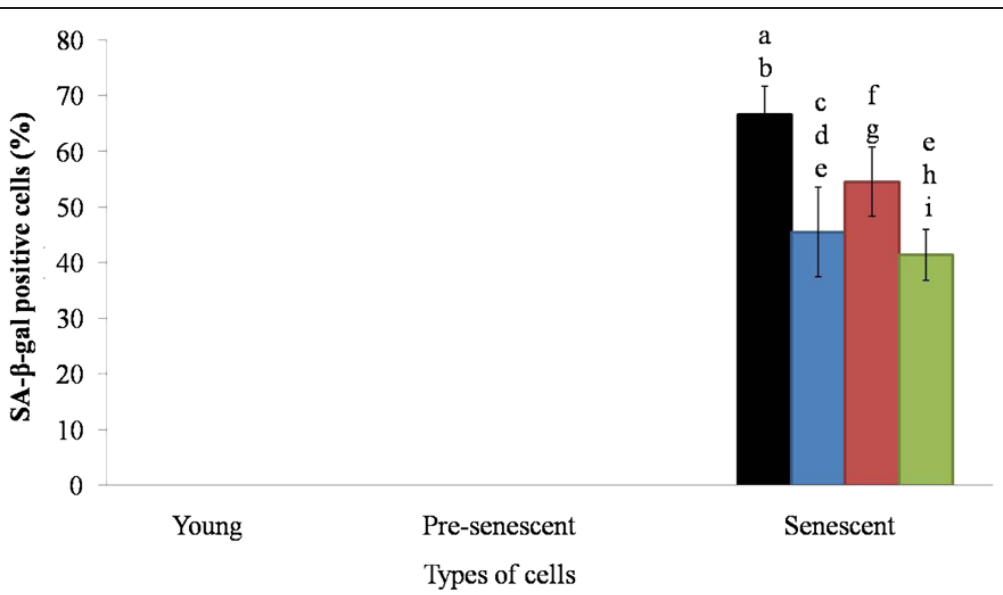

Figure 2 Beta-galactosidase expressions in HDFs. HDFs were treated for $24 \mathrm{~h}$ with $0.2 \mathrm{mg} / \mathrm{ml}$ aqueous extract of $P$. betle, $0.1 \mathrm{mg} / \mathrm{ml}$ hot water extract of C. vulgaris and $0.5 \mathrm{mg} / \mathrm{ml}$ TRF. Black, blue, red and green bars represent control, P. betle, C. vulgaris, and TRF treatments, respectively. ${ }^{a} p<0.05$ compared to young HDFs, ${ }^{b} p<0.05$ compared to pre-senescent HDFs, ${ }^{c} p<0.05$ compared to $P$. betle-treated young HDFs, ${ }^{d} p<0.05$ compared to $P$. betle-treated pre-senescent HDFs, ${ }^{e} \mathrm{p}<0.05$ compared to senescent HDFs, ${ }^{f} \mathrm{p}<0.05$ compared to $C$. vulgaris-treated young HDFs, ${ }^{9} p<0.05$ compared to C. vulgaris-treated pre-senescent HDFs, ${ }^{h} p<0.05$ compared to TRF-treated young HDFs, ${ }^{i} p<0.05$ compared to TRF-treated senescent HDFs. Data are presented as mean $\pm \mathrm{SEM}, \mathrm{n}=6$.

\section{Catalase enzyme activity}

When treated with the extracts and TRF, the young cells displayed significantly reduced catalase activity (Figure 3). The biggest reduction was brought about by TRF, where the activity was reduced from 0.28 to $0.07 \mathrm{mU} / \mathrm{mg}$ protein, followed by $C$. vulgaris extract $(0.17 \mathrm{mU} / \mathrm{mg})$, and $P$. betle extract $(0.21 \mathrm{mU} / \mathrm{mg})$. The effects of the treatments were significantly different from each other in this particular age group.

Catalase activity in the pre-senescent cells $(0.34 \mathrm{mU} / \mathrm{mg})$ was significantly higher than that of the young cells, and was significantly decreased by half, by treatments with P. betle extract $(0.17 \mathrm{mU} / \mathrm{mg})$ and $\mathrm{TRF}(0.18 \mathrm{mU} / \mathrm{mg})$, but not by the $C$. vulgaris extract $(0.37 \mathrm{mU} / \mathrm{mg})$. Treatments of the pre-senescent cells by $C$. vulgaris and TRF significantly produced different effects in the pre-senescent HDFs.

The senescent HDFs displayed a significantly lower catalase activity $(0.26 \mathrm{mU} / \mathrm{mg}$ protein $)$ than that of the young and pre-senescent cells. Treatment of the senescent cells with $P$. betle significantly reduced the catalase activity $(0.16 \mathrm{mU} / \mathrm{mg}$ protein), but not with C. vulgaris and TRF. However, the treatment with C. vulgaris significantly increased and decreased the catalase activities in senescent HDFs as compared to the young and pre-senescent HDFs, respectively; and increased the

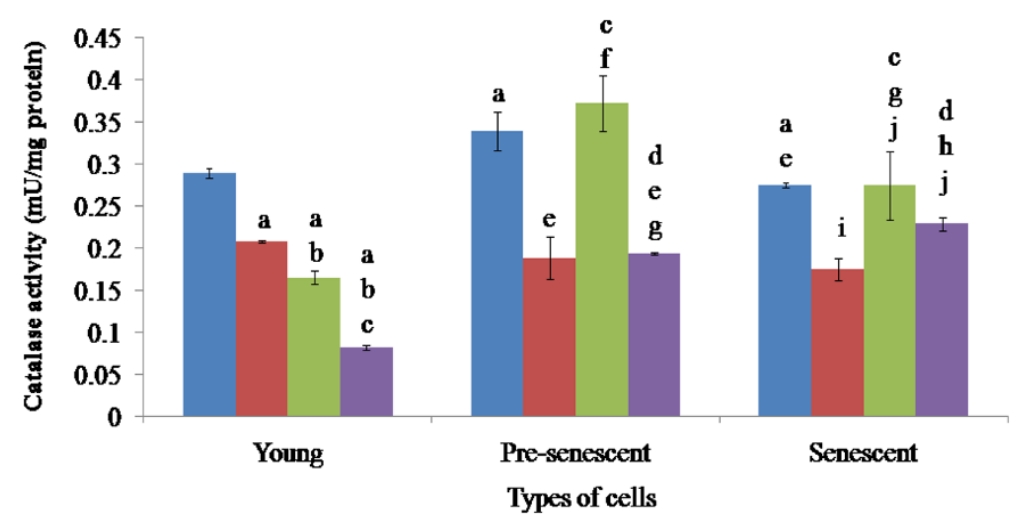

Figure 3 Catalase activities of HDFs treated with P. betle, C. vulgaris and TRF. Blue, red, green and violet bars represent control, $P$. betle, $C$. vulgaris, and TRF treatments, respectively. ${ }^{a} p<0.05$ compared to young HDFs, ${ }^{b} p<0.05$ compared to $P$. betle-treated young HDFs, ${ }^{C} p<0.05$ compared to C. vulgaris-treated young HDFs, ${ }^{d} p<0.05$ compared to TRF-treated young HDFs, ${ }^{\mathrm{p} p}<0.05$ compared to pre-senescent HDFs, ${ }^{f} p<$ 0.05 compared to $P$. betle-treated pre-senescent HDFs, ${ }^{9} p<0.05$ compared to $C$. vulgaris-treated pre-senescent HDFs, ${ }^{h} p<0.05$ compared to TRFtreated pre-senescent HDFs, ${ }^{i} p<0.05$ compared to senescent HDFs, ${ }^{j} p<0.05$ compared to $P$. betle-treated senescent HDFs. Data are presented as mean $\pm S E M, n=6$. 
activity compared to the treatment by $P$. betle. Compared to the other age groups, treatment by TRF in this age group produced a significantly higher activity. Treatment with TRF also produced a significantly higher catalase activity, in comparison to that by the $P$. betle extract.

\section{Superoxide dismutase enzyme (SOD) activity}

The SOD activity was the highest in the pre-senescent (630 $\mathrm{mU} / \mathrm{mg}$ protein), followed by the senescent (395 $\mathrm{mU} / \mathrm{mg}$ protein), and the young HDFs (355 mU/ mg protein, Figure 4).

The SOD activity in the young cells was significantly reduced following treatment with $P$. betle $(100 \mathrm{mU} / \mathrm{mg}$ protein). Treatment with TRF (405 mU/mg protein) resulted in a significantly higher activity than the ones treated with $P$. betle and $C$. vulgaris $(250 \mathrm{mU} / \mathrm{mg}$ protein).

Following treatment with $P$. betle, the activity in presenescent cells was significantly decreased $(400 \mathrm{mU} / \mathrm{mg}$ protein), but significantly higher than that in the young. Treatment with $C$. vulgaris (875 $\mathrm{mU} / \mathrm{mg}$ protein) and TRF (750 $\mathrm{mU} / \mathrm{mg}$ protein) significantly increased the activity of SOD in pre-senescent HDFs as compared to young treated HDFs.

Treatment of the senescent cells $(395 \mathrm{mU} / \mathrm{ml}$ protein) with $C$. vulgaris (250 $\mathrm{mU} / \mathrm{mg}$ protein) and TRF (253 $\mathrm{mU} / \mathrm{mg}$ protein) resulted in a significant reduction of SOD activity, even when compared to those in the pre-senescent cells. TRF treatment produced significantly lowered SOD activity as compared to young and pre-senescent TRF treated groups. $P$. betle treatment only produced significant effect when compared to the other age groups.

\section{Glutathione peroxidase enzyme activity}

In young HDFs (Figure 5), the activity of GPx $(0.61 \mathrm{mU} / \mathrm{mg}$ protein) was significantly reduced by treatment with P. betle $(0.16 \mathrm{mU} / \mathrm{mg}$ protein $)$ and TRF $(0.20 \mathrm{mU} / \mathrm{mg}$ protein). Treatment with $C$. vulgaris $(0.50 \mathrm{mU} / \mathrm{mg}$ protein) did not lower the enzyme activity, which was significantly produced a higher enzyme activity than the $P$. betle treatment. Treatment with TRF produced a significant effect when compared to the other two extracts.

The activity of GPx in the pre-senescent cells (0.46 $\mathrm{mU} / \mathrm{mg}$ protein) was significantly affected by all the treatments. $P$. betle extract $(0.24 \mathrm{mU} / \mathrm{mg}$ protein $)$ and TRF $(0.34 \mathrm{mU} / \mathrm{mg}$ protein $)$ significantly reduced the enzyme activity, but $C$. vulgaris $(0.91 \mathrm{mU} / \mathrm{mg}$ protein) produced the opposite effect, which was also significantly higher than that in the young cells.

The activity of GPx in the senescent cells $(0.25 \mathrm{mU} / \mathrm{mg}$ protein) was significantly lower than that of the young HDFs. The enzyme activity was significantly increased when the senescent cells were treated with $C$. vulgaris (0.48 $\mathrm{mU} / \mathrm{mg}$ protein) and TRF (0.32 $\mathrm{mU} / \mathrm{mg}$ protein), but no significant effect was observed from $P$. betle treatment $(0.16 \mathrm{mU} / \mathrm{mg}$ protein). The effect of the $C$. vulgaris treatment was significantly lower than that observed in the pre-senescent cells, but higher than the effect produced by $P$. betle treatment in the pre-senescence. The effect resulting from the TRF treatment was also significantly different than that produced by $P$. betle and C. vulgaris extracts in the same age group.

\section{Discussion}

The present study is focused on comparing the effect of P. betle, C. vulgaris and TRF on cellular ageing in HDFs. The morphology of the HDFs was shown to change with

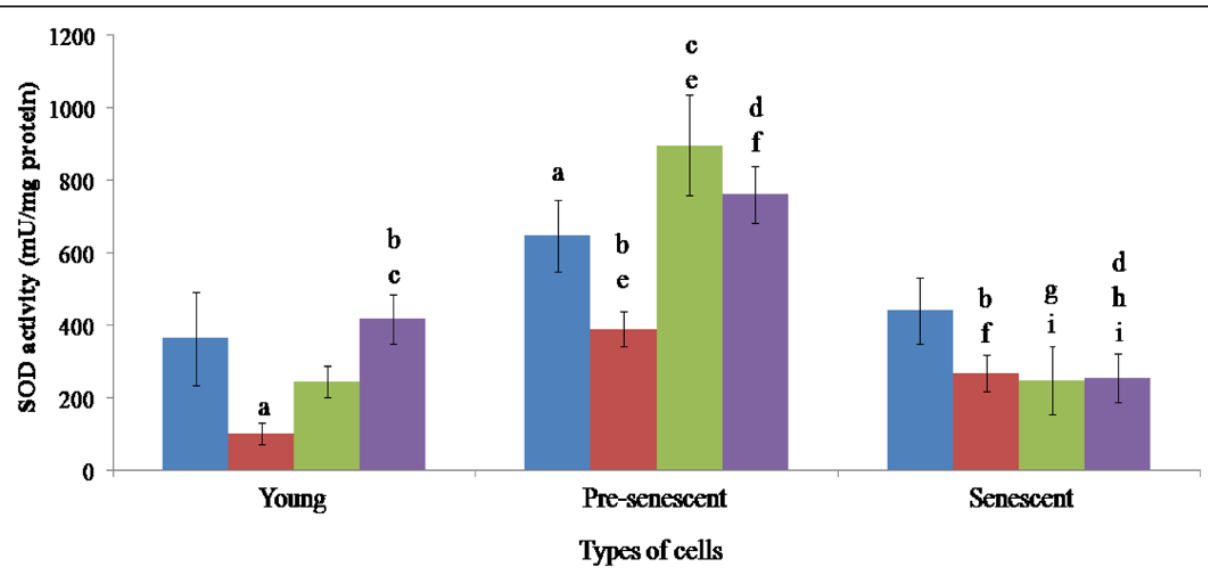

Figure 4 SOD activities of HDFs treated with $P$. betle, $C$. vulgaris and TRF. Blue, red, green and violet bars represent control, $P$. betle, C. vulgaris, and TRF treatments, respectively. ${ }^{a} p<0.05$ compared to young HDFs, ${ }^{b} p<0.05$ compared to $P$. betle-treated young HDFs, ${ }^{C} p<0.05$ compared to $C$. vulgaris-treated young HDFs, ${ }^{d} p<0.05$ compared to TRF-treated young HDFs, ${ }^{e} p<0.05$ compared to pre-senescent HDFs, ${ }^{f} p<0.05$ compared to $P$. betle-treated pre-senescent HDFs, ${ }^{9} p<0.05$ compared to C. vulgaris-treated pre-senescent HDFs, ${ }^{h} p<0.05$ compared to TRF-treated pre-senescent HDFs, ${ }^{i} p<0.05$ compared to senescent HDFs. Data are presented as mean \pm SEM, $n=6$. 


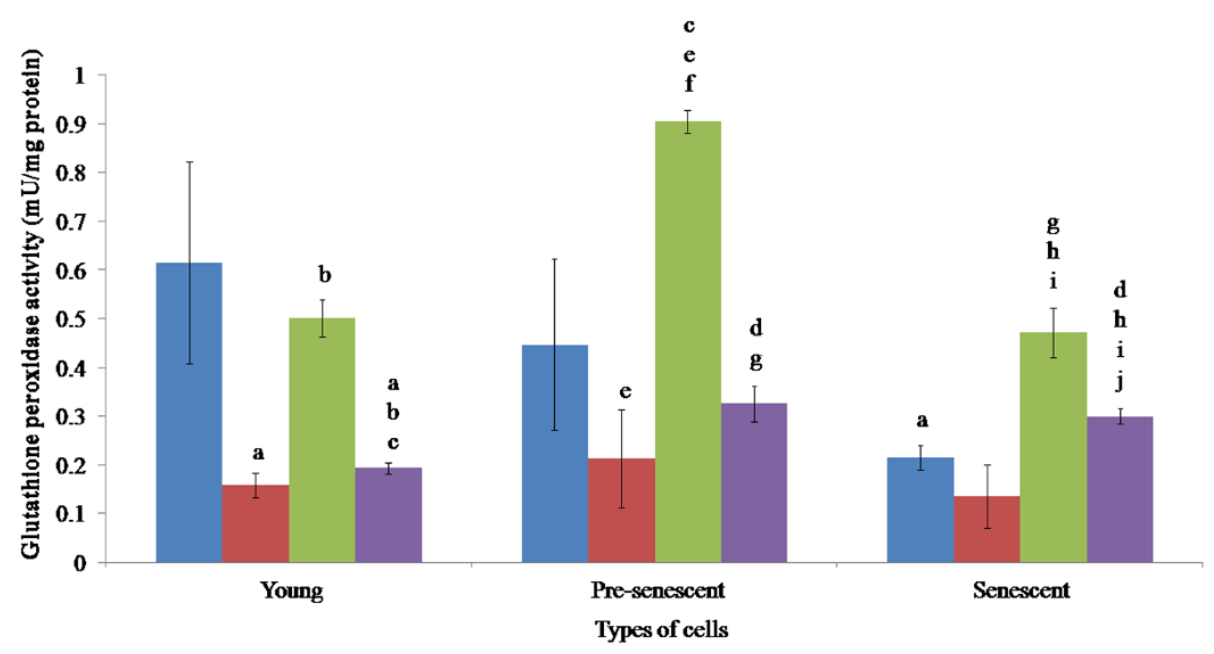

Figure 5 Glutathione peroxidase activities of HDFs treated with P. betle, C. vulgaris and TRF. Blue, red, green and violet bars represent control, P. betle, C. vulgaris, and TRF treatments, respectively. ${ }^{\mathrm{a}} \mathrm{p}<0.05$ compared to young HDFs, ${ }^{\mathrm{b}} \mathrm{p}<0.05$ compared to $P$. betle -treated young HDFs, ${ }^{c} p<0.05$ compared to $C$. vulgaris-treated young HDFs, ${ }^{d} p<0.05$ compared to TRF-treated young HDFs, ${ }^{e} p<0.05$ compared to pre-senescent HDFs, ${ }^{f} \mathrm{p}<0.05$ compared to $P$. betle-treated pre-senescent HDFs, ${ }^{9} \mathrm{p}<0.05$ compared to $C$. vulgaris-treated pre-senescent HDFs, ${ }^{h} p<0.05$ compared to senescent HDFs, ${ }^{i} p<0.05$ compared to $P$. betle-treated senescent HDFs, ${ }^{j} p<0.05$ compared to $C$. vulgaris-treated pre-senescent HDFs. Data are presented as mean $\pm \mathrm{SEM}, \mathrm{n}=6$.

age, similar to previous studies that showed senescing cells undergo morphological changes to become flattened and enlarged in size $[31,36]$. The size increment was largely due to the increasing number and mass of mitochondria and autophagic vacuoles, and the accumulation of nuclear proteins and other metabolites [5]. Mitochondria provide cellular energy in the form of ATP, but the accumulating oxidative damage during ageing lowers the function of mitochondria [37]. In turn, the size and number of mitochondria was increased to counteract the decreasing biogenesis ability of mitochondria during ageing. Accumulation of nuclear protein caused the expansion of the nucleus, contributing to the enlargement of the cells [38], while the rise in the number of auto lysosomal enzymes contributes to enlargement of vacuoles [39]. Ageing is an irreversible process $[5,11]$. However, treatment of the senescent HDFs with the P.betle and C. vulgaris extracts and TRF reduced the number of SA $\beta$-gal positive cells, suggesting a reversal in cellular ageing is possible [31].

SA $\beta$-gal is a common in vitro ageing marker, which has been observed in senescent human diploid fibroblasts (HDFs), skin, liver, muscle, and endothelial cells [40]. Our result showed that only senescent (passage 30) cells displayed blue-stained cells. Increased activity of $\beta$ galactosidase (a lysosomal enzyme) is associated to auto lysosomal activity, which may cause cells to undergo ageing and finally death [39].

Our study demonstrated that $P$. betle and TRF possessed anti-ageing effect, based on the reduced expression of SA $\beta$-gal, in senescent HDFs. P. betle contains phenolic components such as kavibetol and alylpirocatechol [16]. The antioxidant actions of these components could reduce oxidative damage that occurred during ageing. Modulation of oxidative stress can directly control ageing [41]. Telomere shortening and accumulation of DNA damage are the mechanisms that force cells to undergo ageing. $\alpha$-Tocopherol and $\gamma$ tocotrienol have been reported to have protective effect against telomere shortening by increasing telomerase activity and protect DNA damage induced by hydrogen peroxide $[31,42,43]$. As an antioxidant, TRF reduces oxidative stress and low density lipoprotein peroxidation [44], by donating electron in the form of phenolic hydrogen to the lipid radical [45]. TRF also provide protective effect towards Alzheimer disease, which is caused by oxidative damage [46].

Relatively, C. vulgaris exhibited an anti-ageing effect to a lesser extent. Although the number of positive SA $\beta$ gal senescent cells were reduced, but the effect was not a significant one. This trend was similar with an earlier study where there was no significant reduction in DNA oxidative damage in C. vulgaris-treated leukocyte [47].

Manifestation of ageing is accompanied by the involvement of antioxidant molecules. Antioxidant enzymes such as catalase, SOD and GPx play a major role in counteracting the effect of oxidative stress, which is a factor of ageing $[6,48]$. These enzymes are often targeted in anti-ageing and drug discovery research $[48,49]$. Furthermore, a study by Remmen et al. (2004) showed that 
mice lacking both SOD and GPx genes were more sensitive towards oxidative stress [50].

Our results showed that in ageing HDFs, catalase and GPx activities were decreased, while SOD activity was at its peak during pre-senescent stage. SOD level has been shown to be age-independent [51]. These effects were also observed in human fibroblasts under oxidative stress induced by ultraviolet-A irradiation and 8metocypsoralen [49].

As ageing progresses, increased SOD activity resulted in a high level of hydrogen peroxide, but reduced catalase and GPx activities have caused the accumulation of hydrogen peroxide [49]. GPx reduces hydrogen peroxide by oxidizing GSH, and catalase converts hydrogen peroxide to water and oxygen $[8,13]$. Thus, the increasing SOD activity, and decreasing GPx and catalase activities during ageing damaged the antioxidant enzyme homeostasis within a cells and forced it to undergo ageing.

Compounds like chavibetol and alylpirocatechol from $P$. betle $[16,17,52]$ are believed to be able to prevent degenerative diseases [53]. This study demonstrated that treatment of young, pre-senescent and senescent HDFs with aqueous extract of $P$. betle reduced the activity of catalase. The same effect was observed in rats that received $P$. betle ethanolic extract as a pre treatment, later induced with cadmium chloride to induce oxidative stress [48]. The reduction in catalase catalytic activity could be attributed to the reduced amount of $\mathrm{H}_{2} \mathrm{O}_{2}$ available, by the ability of $P$. betle to reduce oxidative stress in fibroblast cells by non-enzymatic antioxidant activity [54]. The activity of $P$. betle was supported by a discovery made by Dasgupta and De (2004), which proved that aqueous extract of $P$. betle leaves reduced non-enzymatic lipid peroxidation by free radical scavenging effect [18]. The $P$. betle extract also reduced SOD activities in young and pre-senescent HDFs, which is similar to a study done by Prabu et al. (2012). In their study, rats were induced with cadmium chloride to induce oxidative stress. Rats that received $P$. betle ethanolic extract as a pre treatment, showed a reduced SOD activity [48].

In this study, C. vulgaris hot water extract significantly reduced and increased the activities of SOD and GPx, respectively in senescent HDFs. C. vulgaris contains polyphenol and flavonoid that portray antioxidant activity by free radical scavenging. Extracts isolated from C. vulgaris posses redox properties, which are vital in absorbing and neutralizing free radicals, quenching ROS, and decomposing peroxides [24]. The potent antioxidant activity displayed by flavonoids owes to the hydroxyl group substituent on the flavonoid nucleus [55]. Nonenzymatic antioxidant activity of $C$. vulgaris might have reduced superoxides, hence the reduction in SOD activity, which may be attributed to the down-regulation of
SOD expression. This resulted in a net increase in hydrogen peroxide level, which then brought about the increase in GPx activity [49].

TRF from palm oil consists of $75 \%$ tocotrienol and $25 \%$ tocopherol [44]. Tocopherol is a good cellular antioxidant due to its ability to stop the peroxidation of polyunsaturated fatty acid at the biological membrane [26], by removing lipid radical peroxyl [56]. A study by Halliwell \& Gutteridge (2002) [57] also showed that lipid radical peroxyl is more susceptible to react with TRF, compared to lipids in the membrane, due to the presence of unsaturated side chain [27]. Choi and Lee (2009) also demonstrated that TRF is more effective than the other fractions they produced, in neutralizing free radicals and lipid radical peroxyl and destroying prooxidant metal [26]. This study has shown that TRF effectively reduced SOD activity, but raised glutathione peroxidise activity, which was the same effect achieved by C. vulgaris treatment.

The present study demonstrated that during ageing, HDFs treated with $C$. vulgaris exhibited the highest antioxidant enzyme activities, compared to those treated with $P$. betle and TRF. C. vulgaris contains lowest antioxidants compared to $P$. betle and TRF. Hence, fibroblasts treated with $C$. vulgaris had to respond with increasing antioxidant enzyme activities to maintain the redox balance [11]. This outcome was similar with a study showing that SOD and GPx increased in heart allograph with increased oxidative damage [58].

Furthermore, previous study showed that total content polyphenol of $C$. vulgaris was $1.34 \times 10-2 \mathrm{mg}$ galic $\mathrm{acid} / \mathrm{mg}$ [24]. On the other hand, total content polyphenol of $P$. betle variety Kauri was $0.96 \mathrm{mg}$ galic acid/mg. Furthermore, TRF consists of $85.6 \%$ inhibition in DPPH antioxidant assay compared to quercetin [59]. Relatively, C. vulgaris contained less antioxidants compared to $P$. betle and TRF.

\section{Conclusion}

In this study, the level of SA $\beta$-gal of HDFs increased with age. Aqueous extract of $P$. betle and TRF were able to substantially delay the ageing of fibroblast cells, while $C$. vulgaris generated a weaker outcome. $P$. betle showed the strongest antioxidant activity by reducing SA $\beta$-gal expression, catalase activities in all age groups, and SOD activity. TRF exhibited a strong antioxidant activity by reducing SA $\beta$-gal expression, and SOD activity in senescent HDFs. C. vulgaris extract managed to reduce SOD activity in senescent HDFs. Nevertheless, this study requires further investigation in order to elucidate the exact mechanism of antioxidant activities of the extracts and TRF. 


\section{Abbreviations}

HDFs: Human diploid fibroblasts; TRF: Tocotrienol-rich fraction;

SOD: Superoxide dismutase; SA $\beta$-gal: Senescence-associated $\beta$-galactosidase; GPx: Glutathione peroxidase.

\section{Competing interests}

The authors declare that they have no competing interests.

\section{Authors' contributions}

SM was the Principal Investigator who designed the study and revised the manuscript. TWY carried out the lab work and drafted the manuscript. FACR, KTA and YAMY were involved in data acquisition and revising the manuscript. All authors read and approved the final manuscript.

\section{Acknowledgements}

This study was funded by the Ministry of Higher Learning under the Fundamental Research Grant Scheme UKM-FF-03-FRGS0036-2010 and Universiti Kebangsaan Malaysia Grant UKM-DLP-2011-042.

Received: 27 November 2012 Accepted: 13 August 2013 Published: 16 August 2013

\section{References}

1. Farooqui T, Farooqui AA: Aging: an important factor for the pathogenesis of neurodegenerative diseases. Mech Ageing Dev 2009, 130:203-215.

2. Sinclair DA, Oberdoerffer $P$ : The ageing epigenome: damaged beyond repair? Ageing Res Rev 2009, 8(3):189-198.

3. Srivastava VK, Busbee DL: Replicative enzymes and ageing: importance of DNA polymerase alpha function to the events of cellular ageing. Ageing Res Rev 2002, 1(3):443-463.

4. Mammone T, Gan D, Favouzi-Youssefi R: Apoptotic cell death increases with senescence in. Cell Biol Int 2006, 30:909.

5. Boraldi F, Annovi G, Tiozzo R, Sommer P, Quaglino D: Comparison of ex vivo and in vitro human fibroblast ageing models. Mech Ageing Dev 2010, 131(10):625-635.

6. Harman D: Ageing: a theory based on free radical and radiation chemistry. J Gerontol 1956, 11(3):298-300.

7. Wickens AP: Ageing and the free radical theory. Respir Physiol 2001, 128(3):379-391.

8. Limon-Pacheco J, Gonsebatt M: The role of antioxidant-related enzyme in protective response to environmentally induced oxidative stress. Mutat Res 2009, 674(1-2):137-147.

9. Islam KM, Howlader MA, Kundu GC, Bulbul IJ, Ahsan MR: Free radical scavenging activity of chloroform and ethyl acetate extracts of leaves of Piper betle Linn. Libyan Agriculture Res Cent J Int 2010, 1(6):384-387.

10. Radak Z, Takahasi R, Kumiyama A, Nakamoto H, Ohno H, Ookawara T, et al: Effect of aging and late onset dietary restriction on antioxidant enyzmes and proteasome activities, and protein carbonylation of fat skelatal muscle and tendon. Exp Gerontol 2002, 37:1421-1428.

11. Yu BP, Chung HY: Adaptive mechanisms to oxidative stress during ageing. Mech Ageing Dev 2006, 127(5):436-443.

12. Kim A, Murphy M, Oberley TD: Mitochondrial redox state regulates transcription of the nuclear-encoded mitochondrial protein manganese superoxide dismutase: a proposed adaptive response to mitochondrial redox imbalance. Free Radic Biol Med 2005, 38(5):644-654.

13. Nagababu E, Chrest FJ, Rifkind JM: Hydrogen-peroxide-induced heme degradation in red blood cells: the protective roles of catalase and glutathione peroxidase. Biochim Biophys Acta 2003, 1620(1-3):211-217.

14. Arambewala LS, Arawwawala LD, Ratnasooriya WD: Antidiabetic activities of aqueous and ethanolic extracts of Piper betle leaves in rats. J Ethnopharmacol 2005, 102(2):239-245.

15. Orme WB: Makan sirih. Br Med J 1914, 1(2771):325-326.

16. Bhattacharya S, Banarjee D, Bauri A, Chattopadhyay S, Bandyopadhyay S: Healing property of the Piper betel phenol, allylpyrocatechol against indomethacin-induced stomach ulceration. World J Gastroenterol 2007, 13(27):3705-3713.

17. Bhattacharya S, Subramaniam M, Roychowdhury S, Bauri AK, Kamat JP, Chattopadhyay S, et al: Radioprotective property of the ethanolic extract of Piper betle leaf. J Radiat Res 2005, 46(2):135-171.

18. Dasgupta N, De B: Antioxidant activity of Piper betle L. leaf extract in vitro. Food Chem 2004, 88:219-224.
19. Prakash B, Shukla R, Singh P, Kumar A, Mishra PK, Dubey NK: Efficacy of chemically characterized Piper betle L. essential oil against fungal and aflatoxin contamination of some edible commodities and its antioxidant activity. Int J Food Microbiol 2010, 142(1-2):114-119.

20. Sarkar D, Kundu S, De S, Hariharan C, Saha P, Manna A, et al: The antioxidant activity of allypyrocatechol is mediated via decreased generation of free radicals along with escalation of antioxidant mechanisms. Phytother Res 2012. doi:10.1002/ptr.4720

21. Queiroz ML, Rodrigues AP, Bincoletto C, Figueiredo CA, Malacrida S: Protective effects of Chlorella vulgaris in lead- exposed mice infected with Listeria monocytogenes. Int Immunopharmacol 2003, 3(6):889-900.

22. Janczyk P, Franke $H$, Souffrant WB: Nutritional value of Chlorella vulgaris: effects of ultrasonication and electroporation on digestibility in rats. Anim Feed Sci Technol 2007, 132:163-169.

23. Shibata $S$, Natori $Y$, Nishhara T, Tomisaka K, Matsumoto K, Sansawa H, et al: Antioxidant and anti-cataract effects of Chlorella on rats with streptozocin-induced diabetes. J Nutr Sci Vitamino/ 2003, 49(5):334-339.

24. Wang HM, Pan JL, Chen CY, Chiu CC, Yang MH, Chang HW, Chang JS: Identification of anti-lung cancer extract from Chlorella vulgaris $\mathrm{C}-\mathrm{C}$ by antioxidant property using supercritical carbon dioxide extraction. Process Biochem 2010, 45(12):1865-1872.

25. Sundram K, Gapor A: Vitamin E from palm oil. its extraction and nutritional properties. Lipid Technology 1992, 4:137-141.

26. Choi Y, Lee J: Antioxidant and antproliferative properties of a tocotrienol-rich fraction from grape seeds. Food Chem 2009, 114:1386-1390

27. Serbinova E, Kagan V, Han D, Packer L: Free radical recycling and intramembrane mobility in the antioxidant properties of alphatocopehrol and alpha-tocotrienol. Free Radic Biol Med 1991, 10:263-275.

28. Schaffer S, Müller WE, Eckert GP: Tocotrienols: constitutional effects in aging and disease. J Nutr 2005, 135(2):151-154.

29. Norfaizatul SO, Zetty Akmal CZ, Noralisa AK, Then SM, Wan Zurinah WN Musalmah M: Dual effects of plant antioxidants on neuron cell viability. J Med Plants 2010, 9:113-123.

30. Saad SM, Mohd Yusof YA, Wan Ngah WZ: Comparison between locally produced Chlorella vulgaris and Chlorella vulgaris from Japan on proliferation and apoptosis of liver cancer cell line, HepG2. Malays J Biochem Mol Biol 2006, 13:32-36.

31. Makpol S, Durani LW, Chua KH, Yusof YA, Ngah WZ: Tocotrienol-rich fraction prevents cell cycle arrest and elongates telomere length in senescent human diploid fibroblasts. J Biomed Biotechnol 2011. doi:10.1155/2011/506171

32. Bradford MM: A rapid and sensitive method for the quantitation of microgram quantities of protein utilizing the principle of protein-dye binding. Analytical Biochemitsry 1976, 72:248-254.

33. Aebi $\mathrm{H}$, Sute $\mathrm{H}$, Feinstein RN: Activity and stability of catalase in blood and tissue of normal and acatalasemic mice. Biochem Genet 1968, 2(3):245-251.

34. Beyer WF, Fridovich I: Assaying for superoxide dismutase activity: some large consequences of minor changes in conditions. Anal Biochem 1987, 161(2):559-566.

35. Paglia DE, Valentine WN: Studies on the quantitative and qualitative characterization of erythrocyte glutathione peroxidase. J Lab Clin Med 1967, 70(1):158-169.

36. Loke C, Nur HM, Mohd FM, Teo S, Nor HA, Yasmin AM, et al: Does Chlorella vulgaris modulate the expression of $\mathrm{COL}$ and MMP genes in skin ageing. Med Health 2010, 5(1):1-12.

37. Huang H-M, Fowler C, Xu H, Zhang H, Gibson GE: Mitochondrial function in fibroblasts with aging in cultutre and/or Alzheimer's disease. Neurobiol Aging 2005, 26:839-848.

38. Cecco MD, Jeyapalan J, Zhao X, Tamamori-Adachi M, Sedivy JM: Nuclear protein accumulation in cellular senescence and arganismal aging revealed with a novel single-cell resolution fluorescence mircroscopy assay. Aging 2011, 3(10):955-967.

39. Gerland L-M, Peyrol S, Lallemand C, Branche R, Magaud J-P, French $\mathrm{M}$ : Association of increased autophagic inclusions labeled for $\beta$-galactosidase with fibroblastic aging. Exp Gerontol 2003, 38:887-895.

40. Dimri GP, Lee X, Basile G, Acosta M, Scott G, Roskelly C, Medrano EE, Linskens M, Rubej I, Pereira-Smith O, Peacocke M, Campisi J: A biomarker that identifies senescent human cells in culture and in ageing skin in vivo. Proc Natl Acad Sci U S A 1995, 92(20):9363-9367. 
41. Salmon AB, Richardson A, Perez VI: Update on the oxidative stress theory of aging: does oxidative stress play a role in aging or healthy aging? Free Radic Biol Med 2010, 48:642-655.

42. Makpol S, Zainudin A, Rahim NA, Yusof YA, Ngah WZ: Alpha-tocopherol modulates hydrogen peroxide-induced DNA damage and telomere shortening of human skin fibroblasts derived from differently aged individuals. Planta Med 2010, 76:869-875.

43. Makpol S, Abidin AZ, Sairin K, Mazlan M, Top GM, Ngah WZ: Y-Tocotrienol prevents oxidative stress-induced telomere shortening in human fibroblasts derived from different aged individuals. Oxid Med Cell Longev 2010, 3(1):35-43.

44. Mutalib MSA, Khaza'ai H, Wahle KWJ: Palm-tocotrienol rich fraction (TRF) is a more effective inhibitor of LDL oxidation and endothelial cell lipid peroxidation than a-tocopherol in vitro. Food Res Int 2003, 36:405-413.

45. Kamal-Eldin A, Appelqvist LA: The chemistry and antioxidant properties of tocopherols and tocotrienols. Lipids 1996, 31(7):671-701.

46. Tiwari V, Kuhad A, Bishnoi M, Chopra K: Chronic treatment with tocotrienol, an isoform of vitamin E, prevents intracerebroventricular streptozotocin-induced cognitive impairment and oxidative-nitrosative stress in rats. Pharmacol Biochem Behav 2009, 93:183-189.

47. Lee SH, Kang HJ, Lee H-J, Kang M-H, Park YK: Six-week supplementation with Chlorella has favorable impact on antioxidant status in Korean male smokers. Nutrition 2010, 26:175-183.

48. Prabu SM, Muthumani M, Shagirtha K: Protective effect of Piper betle leaf extract against cadmium-induced oxidative stress and hepatic dysfunction in rats. Saudi J Biol Sci 2012, 19:229-239.

49. Briganti S, Wlaschek M, Hinrichs C, Bellei B, Flori E, Reiber N, et al: Small molecular antioxidants effectively protect from PUVA-induced oxidative stress. Free Radic Biol Med 2008, 45:636-644.

50. Remmen HV, Qi W, Sabia M, Freeman G, Estlack L, Yang H, Guo ZM, Huang TT, Strong R, Lee S, Epstein CJ, Richardson A: Multiple deficiencies in antioxidant enzymes in mice result in a compound increase in sensitivity to oxidative stress. Free Radic Biol Med 2004, 36(12):1625-1634.

51. Oztürk G, Akbulut KG, Güney S, Acuna-Castroviejo D: Age-related changes in the rat brain mitochondrial antioxidative enzyme ratios: Modulation by melatonin. Exp Gerontol 2012. doi:10.1016/j.erger.2012.06.011

52. Lopez-Velez M, Martinez-Martinez F, Del VRC: The study of phenolic compounds as natural antioxidants in wine. Crit Rev Food Sci Nutr 2003, 43:233-244.

53. Roginsky V: Chain breaking antioxidant activity of natural polyphenols as determined during the chain oxidation of methyl linoleate in triton X-100 micelles. Arch Biochem Biophys 2003, 414:261-270.

54. Saravanam R, Prakasam A, Ramesh B, Pugalendi KV: Influence of Piper betle on hepatic marker enzymes and tissu antioxidant status in ethanol-treated Wister rats. J Med Food 2002, 5:197-204.

55. Arora A, Nair MG, Strasburg GM: Structure-activity relationships for antioxidant activities of a series of flavonoids in a liposomal system. Free Radic Biol Med 1998, 24(9):1355-1363.

56. Khan MR, Siddiqui S, Parveen K, Javed S, Diwakar S, Siddiqui WA: Nephroprotective action of tocotrienol-rich fraction (TRF) from palm oil against potassium dichromate $\left(\mathrm{K}_{2} \mathrm{Cr}_{2} \mathrm{O}_{7}\right)$-induced acute renal injury in rats. Chem Biol Interact 2010, 186(2):228-238.

57. Halliwell BB, Gutteridge JMC: Free Radicals in Biology and Medicine. New York: Oxford University Press Inc:; 2002.

58. Schimke L, Schikora M, Meyer R, Dubel HP, Modersohn D, Kleber FX, Baumann G: Oxidative stress in the human heart is associated with changes in the antioxidative defense as shown after heart transplantation. Mol Cell Biochem 2000, 204(1-2):89-96.

59. Muhanis SP, Top AGM, Murugan D, Mustafa MR: Palm oil tocotrienol fractions restore endothelium dependent relaxation in aortic rings of streptozotocin-induced diabetic and spontaneously hypertensive rats. Nutr Res 2010, 30:209-216.

doi:10.1186/1472-6882-13-210

Cite this article as: Makpol et al: Comparative effect of Piper betle, Chlorella vulgaris and tocotrienol-rich fraction on antioxidant enzymes activity in cellular ageing of human diploid fibroblasts. BMC Complementary and Alternative Medicine 2013 13:210.

\section{Submit your next manuscript to BioMed Central and take full advantage of:}

- Convenient online submission

- Thorough peer review

- No space constraints or color figure charges

- Immediate publication on acceptance

- Inclusion in PubMed, CAS, Scopus and Google Scholar

- Research which is freely available for redistribution 